\title{
Karakteristik Karapas dan Chela sebagai Alat Identifikasi Fosil Kepiting (Decapoda: Brachyura) yang ditemukan di Jawa
}

\section{Characteristics of Carapace and Chela as An Identification Tool for Crab's Fossils (Decapoda: Brachyura) are Found in Java}

\author{
Donan Satria Yudha ${ }^{1 *}$, Krisogonus Yudha Parama Putra ${ }^{2}$, Rury Eprilurahman ${ }^{1}$ \\ ${ }^{1}$ Laboratorium Sistematika Hewan, Fakultas Biologi, Universitas Gadjah Mada \\ Jl. Teknika Selatan Sekip Utara, Sleman, Daerah Istimewa Yogyakarta 55281, Indonesia \\ ${ }^{2}$ Prodi Biologi, Fakultas Biologi, Universitas Gadjah Mada \\ Jl. Teknika Selatan Sekip Utara, Sleman, Daerah istimewa Yogyakarta 55281, Indonesia \\ Email:donan_satria@ugm.ac.id_*Penulis Korespondensi
}

\begin{abstract}
Brachyuran crabs are grouped into 53 families spread all over the world. In Indonesia, there are 40 non-freshwater crab families and three endemic freshwater crab families, namely: Potamidae, Gecarcinudae, and Parathelpusidae. Carapace and chela (claws) of crabs are body parts that are used to determine taxonomical identification. In Indonesia has been found several fossil fragments of crabs and mostly are carapace and chela. There were no guidance to determine the taxonomical identification of fossils crabs based on its carapace and chela, so it needs to be studied. Therefore, this study aims to examine the morphological characters of carapace and claws as diagnostic characters of crabs so that they can be used in the identification of crab fossils. The specimens studied were collection of the Laboratory of Animal Systematics, Faculty of Biology, Universitas Gadjah Mada. The method used are the comparison of morphology and characteristics of carapace and claws and reference studies. The results showed that the characteristics of the carapace and claws, including: carapace shape, lateral and dorsal carapace ornamentation, enlarged claws, tubercles on the claw teeth, and claw shape, can be used as references to determine the taxonomical group of brachyuran fragments fossils found in Indonesia especially in Java Island.
\end{abstract}

Keywords: Crab, Identification, Carapace, Chela, Java

\begin{abstract}
Abstrak
Kepiting infraordo Brachyura dikelompokkan ke dalam 53 familia yang tersebar di seluruh dunia. Di Indonesia dapat ditemukan 40 familia kepiting non air tawar dan tiga familia endemik kepiting air tawar, yaitu: Potamidae, Gecarcinudae, dan Parathelpusidae. Karapas dan capit (chela) merupakan bagian tubuh kepiting yang dapat digunakan untuk identifikasi taksonomi. Beberapa fragmen fosil kepiting yang dijumpai di Indonesia biasanya berupa bagian karapas dan capit. Panduan mengenai karakter morfologi karapas dan capit anggota infraordo Brachyura belum tersedia terutama untuk identifikasi fosil kepiting di Indonesia, sehingga perlu dikaji. Oleh karena itu, penelitian ini bertujuan untuk mengkaji karakter morfologi karapas dan capit sebagai karakter diagnostik kepiting sehingga dapat dimanfaatkan dalam identifikasi fosil kepiting. Spesimen yang diteliti adalah koleksi dari Laboratorium Sistematika Hewan Fakultas Biologi, Universitas Gadjah Mada. Metode yang digunakan yaitu komparasi morfologi dan karakteristik dari karapas dan capit serta studi referensi. Hasil penelitian menunjukkan bahwa karakter karapas dan capit, meliputi: bentuk karapas, ornamentasi karapas bagian lateral dan dorsal, salah satu capit membesar, tuberkula pada gigi capit, dan bentuk capit, dapat digunakan untuk mengidentifikasi jenis kepiting infraordo Brachyura dan dapat dijadikan referensi untuk identifikasi fragmen fosil kepiting yang dijumpai di Indonesia terutama di Pulau Jawa.
\end{abstract}

Kata Kunci: Kepiting, Identifikasi, Karapas, Capit, Jawa 


\section{Pendahuluan}

Kepiting merupakan kelompok hewan anggota ordo Decapoda yang dibagi ke dalam dua infraordo besar, yaitu infraordo Anomura dan infraordo Brachyura. Perbedaan mendasar dari kedua infraordo tersebut adalah pada bagian anggota gerak, dimana infraordo Anomura hanya memiliki empat anggota gerak, sementara infraordo Brachyura memiliki lima anggota gerak. Satu pasangan anggota gerak kedua infraordo tersebut memiliki peran sebagai lengan makan yang disebut dengan capit.

Infraordo Brachyura yang umum dikenal sebagai kepiting sejati memiliki karakteristik umum dimana tubuhnya tersusun dari cangkang (karapas) yang terkeratinisasi dan memiliki kaki berjumlah sepuluh buah atau lima pasang. Selain itu, kepiting sejati memiliki ukuran panjang dan lebar karapas yang relatif sama, memiliki karapas yang tertekan secara marginal, memiliki sternum yang melebar serta memiliki pleon pada bagian perut yang tertekuk yang menyerupai ekor. Bagian capit terdiri dari dua bagian, yaitu bagian chela dan bagian cheliped dengan chela dianalogikan sebagai tangan dan cheliped sebagai lengan. Tubuh kepiting infraordo Brachyura tersusun dari zat kitin dan memiliki panjang serta lebar yang hampir sama yang tertekan secara dorsoventral. Penciri lain adalah ada tidaknya ornamentasi pada bagian karapas dan chela (Ng, 1998; Schultz, 2014).

Kepiting infraordo Brachyura memiliki beragaman jenis yang melimpah di alam. Menurut Guinot dalam Ng (2004) kepiting dapat dikelompokkan ke dalam 53 familia, dan delapan jenis di antara merupakan jenis kepiting air tawar. Di Asia Tenggara sendiri, dari delapan familia kepiting air tawar tersebut, ditemukan jenis kepiting yang masuk dalam tiga familia yang merupakan jenis endemik. Tiga familia tersebut antara lain: Potamidae, Gecarcinudae dan Parathelpusidae. Sementara itu dari 45 famili kepiting non air tawar, ditemukan 40 familia yang dapat ditemukan di Asia Timur, Asia Tenggara dan Kepulauan Pasifik (Ng, 1998; Ng, 2004).

Bagian dari tubuh kepiting yang dapat diidentifikasi untuk menentukan jenisnya adalah bagian karapas serta chela. Bagian karapas yang merupakan bentuk eksoskeleton dari kepiting tersebut yang dapat menjadi penciri utama satu kepiting dengan kepiting yang lain. Sementara itu pada bagian capit yang dapat diamati secara khas adalah ada tidaknya ornamentasi pada bagian cheliped serta proporsi pasangan capit (Morris, 1980; $\mathrm{Ng}, 1998 ; \mathrm{Ng}, 2004)$. Di Indonesia telah dijumpai beberapa fragmen fosil kepiting. Fragmen fosil yang dijumpai biasanya bagian karapas dan capit (chela). Salah satu penemuan fosil kepiting infraordo Brachyura di Indonesia yang telah dipublikasikan adalah penemuan fosil Martinocarcinus ickerae yang diidentifikasi melalui bentuk karapas di Formasi Nanggulan dan memiliki Usia Kala Eosen hingga Oligosen (Schweitzer, et al, 2009). Di Indonesia belum memiliki panduan mengenai karakter morfologi karapas dan capit anggota infraordo Brachyura terutama untuk identifikasi fosil kepiting.

Oleh karenanya, penelitian ini dilakukan dengan tujuan untuk mengetahui karakter morfologi karapas dan capit beserta ornamentasinya, pada beberapa jenis kepiting yang dijumpai di Indonesia, guna menentukan karakter diagnostiknya. Karakter diagnostik tersebut diharapkan dapat membantu mengidentifikasi fosil fragmen kepiting berupa sisa karapas dan capit yang ditemukan.

\section{Metode Penelitian}

Sampel penelitian adalah beberapa spesies koleksi dari dari Laboratorium Sistematika Hewan, Fakultas Biologi, Universitas Gadjah Mada. Metode yang digunakan adalah: (1) komparasi morfologi dan karakteristik dari bagian karapas serta capit beberapa spesies kepiting, serta (2) studi referensi pada beberapa familia dan genus kepiting, yaitu: Davie, 1987; Davie, 1993; Lemaitre, et al., 2013; Moraes, et al., 2015; Ng, 1998; Ng, 2004; Ng \& Tan, 1984; Shih, et al., 2013; Valinassab, et al., 2012.

Karapas yang diamati meliputi bagian dorsal dan ornamentasi bagian lateral. Bagian dorsal umumnya akan dijumpai ornamentasi yang dapat menjadi karakter diagnostik suatu jenis, yaitu: ada tidaknya lobus epigastris, lobus urogastris, lobus mesobranchialis, lobus protogastris, serta cardiac region. Sementara ornamentasi bagian lateral meliputi: bentuk karapas (dominan memanjang/ melebar/ proporsional), ada tidaknya gigi frontal, lebar 
orbitofrontal, ada tidaknya gigi anterolateral, dan bentuk posterolateral. Sementara bagian capit yang diamati meliputi: ada tidaknya ornamentasi pada bagian cheliped serta proporsi pasangan capit (Gambar 1) (Morris, 1980; Ng, 1998; Ng, 2004).
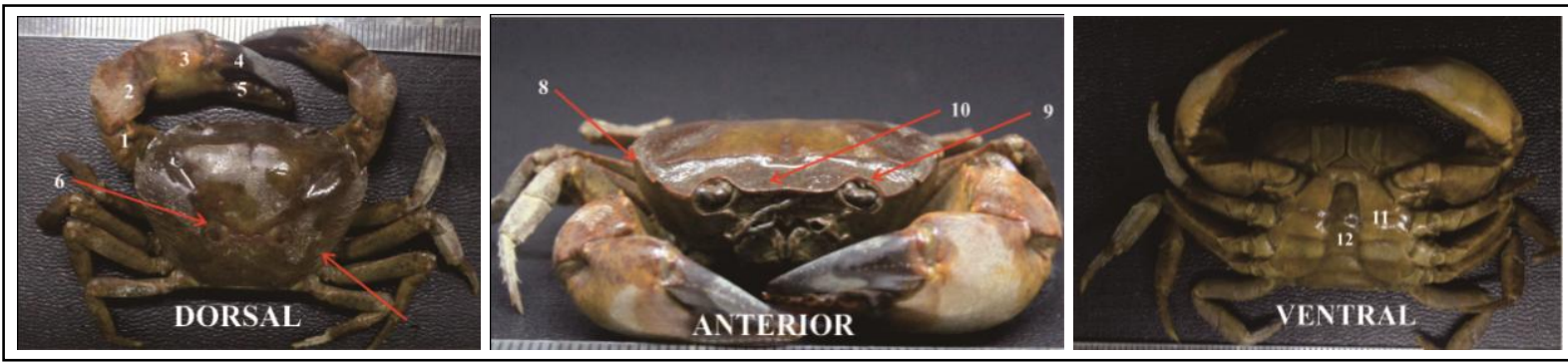

Gambar 1. Bagian tubuh kepiting infraordo Brachyura: 1) Merus; 2) Carpus; 3) Palm; 4) Dactylus; 5). Pollex; 6) Karapas; 7) Bagian Posterolateral; 8) Bagian Anterolateral; 9) Bagian Orbitofrontal; 10) Bagian Frontal; 11) Sternites; 12) Segmen Abdominal (dokumentasi pribadi).

\section{Hasil dan Pembahasan}

\section{Spesimen Kepiting Intertidal dan Laut}

Kelompok kepiting Intertidal dan laut merupakan jenis kepiting yang memiliki variasi ornamentasi,bentuk karapas, dan bentuk capit dibandingkan dengan kepiting air tawar. Spesimen kepiting laut yang diidentifikasi antara lain:

Kelompok kepiting dari familia Pilumnidae merupakan jenis kepiting yang pada umumnya dikenal dari karakteristik karapasnya yang berbentuk heksagonal, persegi transversal, dan oval transversal. Selain itu pada bagian karapas dorsalnya dapat dijumpai tekstur berupa granula ataupun juga tidak bertekstur (halus). Bentuk karapas dorsal dari kepiting familia ini mencembung (dapat terlihat dari bagian lateral). Penciri lain dari kepiting familia ini adalah bagian frontalnya yang umumnya memiliki tiga bentuk, yaitu: rata (halus), tidak terbagi, dan terbagi dalam beberapa segmen (lobus). Selain itu, familia ini juga dapat dikenali karena terdapat gigi atau lobus sejumlah satu hingga empat buah di bagian anterolateralnya. Lobus tersebut dapat bertekstur meruncing maupun tumpul halus (Ng and Tan, 1984). Dua jenis kepiting ditemukan dari spesimen yang diidentifikasi, yaitu: Genus Galene dan Genus Pilumnus.

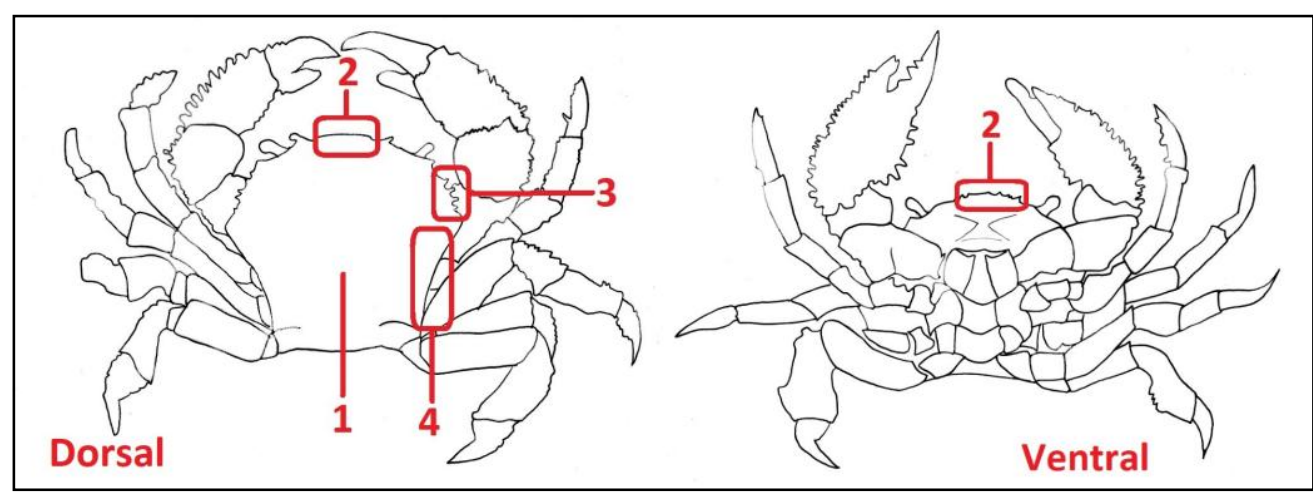

Gambar 2. Bagian tubuh kepiting familia Pilumnidae: 1) Karapas; 2) Bagian Frontal; 3) Bagian Anterolateral; 4) Bagian Posterolateral (Sumber Gambar: modifikasi dari Ng \& Tan, 1984).

Kepiting Genus Galene merupakan memiliki karapas berbentuk persegi panjang melonjong dan pada bagian anterolateral terdapat tiga spina yang memiliki bentuk berbeda. Spina pertama berbentuk triangular (meruncing) dan dua spina yang lain memiliki bentuk rounded (menumpul). Bagian frontal memiliki sulcus (tonjolan seperti gelombang paralel) yang terletak di bagian mediofrontal). Bagian capit (chela) memiliki granula yang tersebar merata. Bagian lateral dan bagian lekukan serta tekstur dorsal karapas dari Galene juga dapat digunakan sebagai karakter diagnostik genus ini. Pada karapas terdapat 
area yang disebut lobus urogastris. Lobus urogastris akan terlihat dengan jelas di bagian median karapas, yang kemudian bersambung dengan lobus mesogastris. Pada Galene lobus urogastris akan berbentuk menyerupai botol (membulat) yang kemudian akan bersambung dengan Cardiac region (area cardiac) nomor dua yang terletak di bagian tengah. Cardiac Region pada Galene berjumlah tiga buah, dimana Cardiac Region nomor dua berbentuk lebih besar. Ketiga Cardiac Region pada Galene berbentuk menyerupai segitiga terbalik serta tampak menonjol membentuk pola-pola (Ng, 1998; Valinassab, et al, 2012).

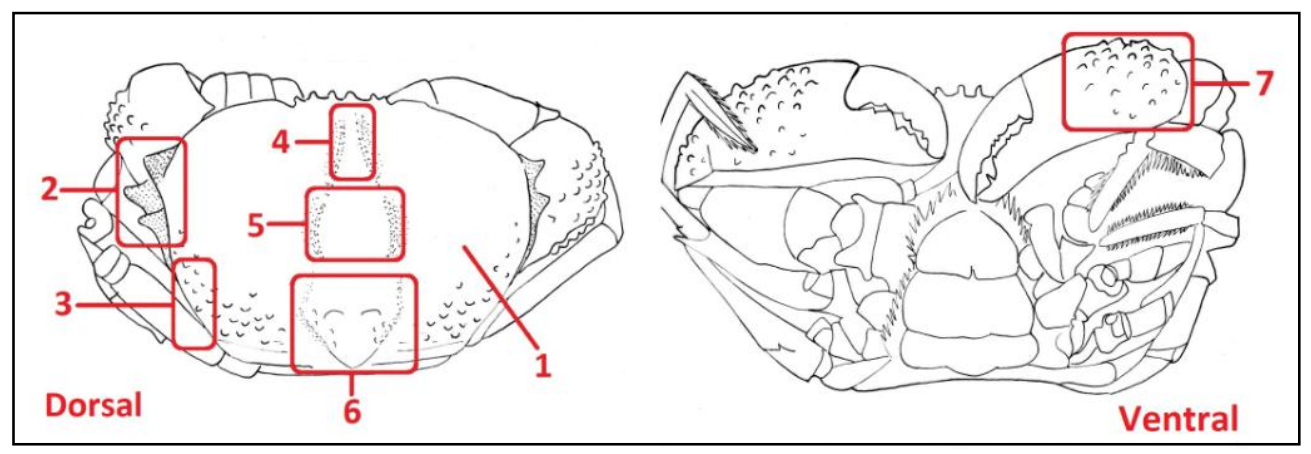

Gambar 3. Bagian tubuh kepiting Genus Galene: 1) Karapas; 2) Bagian Anterolateral; 3) Bagian Posterolateral; 4) Lobus mesogastris; 5) Lobus urogastris; 6) Cardiac Region; 7) Capit (chela) (Sumber Gambar: modifikasi dari Valinassab, et al., 2012)

Kelompok kepiting genus Pilumnus memiliki karakter diagnostik berupa karapas yang berbentuk persegi agak memanjang dan pada bagian sudutnya menumpul. Bagian anterolateral, memiliki spina berjumlah empat. Spina nomor pertama memiliki ukuran yang sangat kecil dan spina nomor terakhir sangat besar. Jika dilihat dari samping, karapas akan terlihat melandai, dan akan tampak dengan jelas bahwa bagian tepinya memipih dan melengkung. Apabila dilihat dari tekstur dan ornamentasi karapas bagian dorsal, maka akan tampak beberapa karakter khas dari genus ini, yaitu: memiliki lobus mesogastris yang memipih dan diapit oleh alur longitudinal lobus urogastricus tampak tertekan dan lebih pipih dibanding genus Galene, bagian lobus protogastris dan lobus urogastris cenderung lebih jelas terlihat dibanding genus Galene, dan posisi lobus protogastris lebih jauh ke bagian lobus urogastris jika dibandingkan dengan posisi lobus mesobranchialis $(\mathrm{Ng}$, 1998; Moraes, et al, 2015).

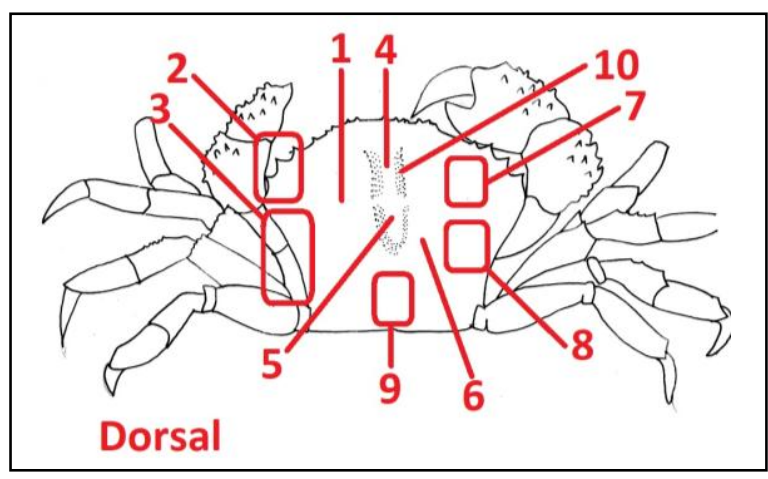

Gambar 4. Bagian tubuh kepiting Genus Pilumnus: 1) Karapas;, 2) Bagian Anterolateral; 3) Bagian Posterolateral; 4) Lobus Mesogastris; 5) Lobus Urogastris; 6) Lobus Epigastris; 7) Lobus Protogastris; 8) Lobus Mesobranchialis; 9) Cardiac Region; 10) Alur Longitudinal (Sumber Gambar: modifikasi dari Moraes, et al., 2015)

Kelompok kepiting lain yaitu kepiting dari familia Portunidae, dengan karakteristik karapas berbentuk heksagonal, oval transversal, dan kadang membulat atau sirkular. Selain itu juga kepiting rajungan memiliki ornamentasi gigi/lobus sejumlah 5-9 
buah yang terletak di bagian anterolateralnya. Bagian posterolateralnya memiliki karakteristik converging atau melengkung agak ke dalam dan bertemu dengan bagian anterolateral pada suatu bagian. Karapas bagian dorsal memiliki kontur datar hingga mencembung bila dilihat dari sisi lateral. Bagian frontal memiliki ciri yang melebar dan pada bagian tepiannya terdapat banyak ornamentasi gigi/lobus (Ng, 1998; Lemaitre, et $a l, 2013)$. Kepiting jenis ini terdapat satu, yaitu genus Portunus.

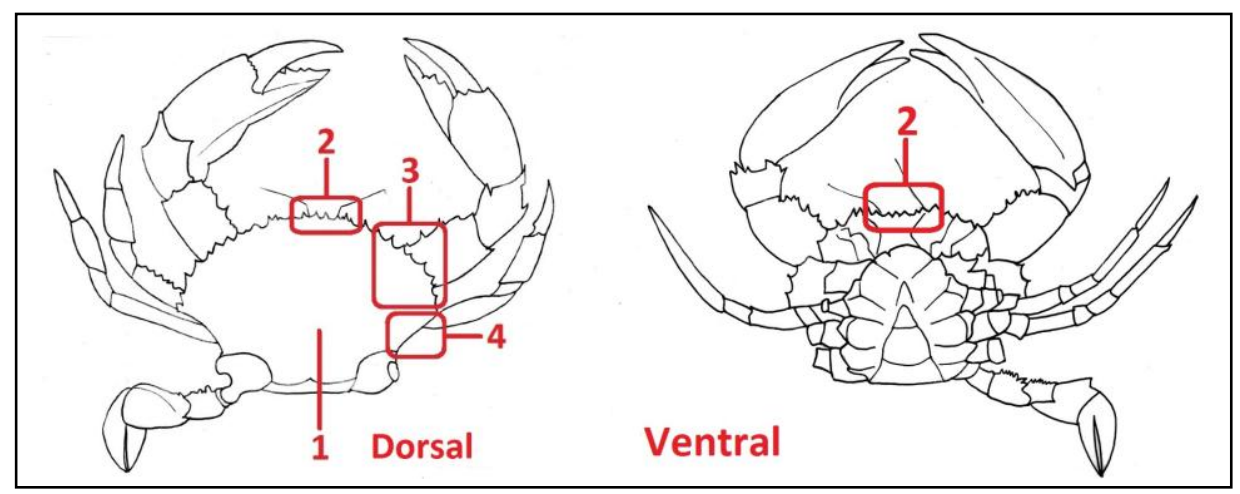

Gambar 5. Bagian tubuh kepiting Familia Portunidae: 1) Karapas; 2) Bagian Frontal; 3) Bagian anterolateral; 4) Bagian Posterolateral (Sumber Gambar: modifikasi dari Lemaitre, et al, 2013).

Kepiting genus Portunus memiliki bentuk karapas heksagonal. Bagian anterolateral dan posterolateral kepiting ini dapat dibedakan dengan jelas. Bagian anterolateral Portunus memiliki tujuh buah ornamentasi gigi/lobus atau bahkan kurang. Selain itu juga kekhasan dari kepiting Portunus yaitu memiliki gigi terakhir di bagian antara anterolateral dan posterolateral yang membesar dan menajam (berbentuk seperti spina).
Kepiting Portunus memiliki empat gigi/lobus yang tampak lebih besar jika dibandingkan dari gigi/lobus pada bagian anterolateral, seperti halnya kepiting familia Portunidae. Selain itu terdapat lekukan antar gigi baik di bagian frontal maupun anterolateral. Lekukan pada bagian anterolateral lebih dalam dibandingkan yang terdapat di bagian frontal (Davie, 1987; $\mathrm{Ng}, 1998)$.

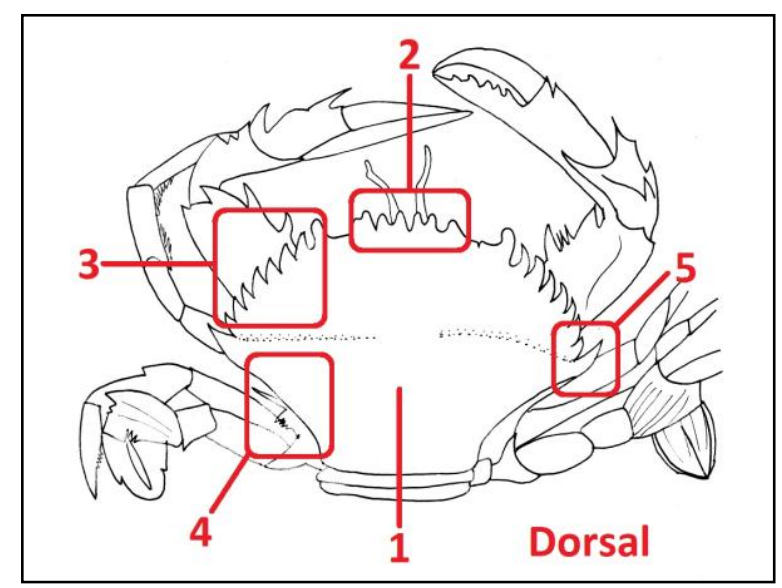

Gambar 6. Bagian tubuh kepiting Genus Portunus: 1) Karapas; 2) Bagian Frontal; 3) Bagian Anterolateral; 4) Bagian Posterolateral; 5) Spina membesar (Sumber Gambar: modifikasi dari Davie, 1987).

Jenis kepiting familia Grapsidae merupakan jenis kepiting yang memiliki habitat di zona intertidal dan umum dijumpai di bagian hilir sungai. Penelitian ini didapatkan dua subfamilia, yaitu subfamilia Sesarminae dan subfamilia Varuninae. Kepiting ini memiliki bentuk karapas yang khas, yaitu kotak/persegi dengan punggung bagian lateral (Antero-posterolateral) yang melandai/ miring dan, tidak terdapat batas yang jelas antara anterolateral dan posterolateral, sehingga seakan-akan kedua sisi tersebut saling bersatu. 
Bagian frontal yang lebih melebar dibandingkan bagian orbital dan di bagian gigi atau lobus sejumlah satu hingga dua buah frontal kepiting ini juga terdapat ornamentasi

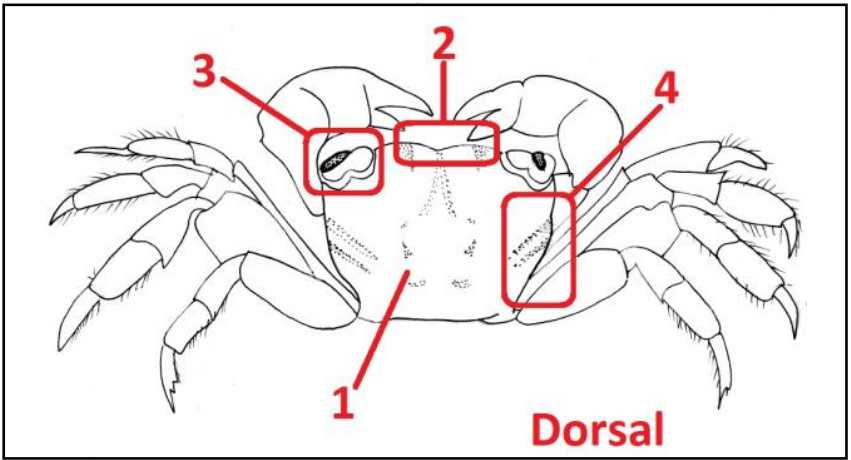

Gambar 7. Bagian tubuh kepiting Familia Grapsidae-subfamilia Sesarminae: 1)Karapas; 2) Bagian Frontal; 3) Bagian Orbitofrontal; 4) Bagian Antero-posterolateral (Sumber Gambar: Davie, 1993)

Subfamilia Varuninae memiliki karakteristik berupa karapas cokelat cenderung kotak dengan permukaan yang halus dan pada bagian tepi depan lurus. Pada bagian sisi samping karapas terdapat tiga buah gigi antero-lateral pada setiap sisinya (Gambar 2). Ciri yang khas dari subfamilia Varuninae adalah pada bagian dactylus/jari, propodus dan karpus pipih, pada bagian pinggirnya terdapat seta yang panjang dan rapat $(\mathrm{Ng}, 1998)$.

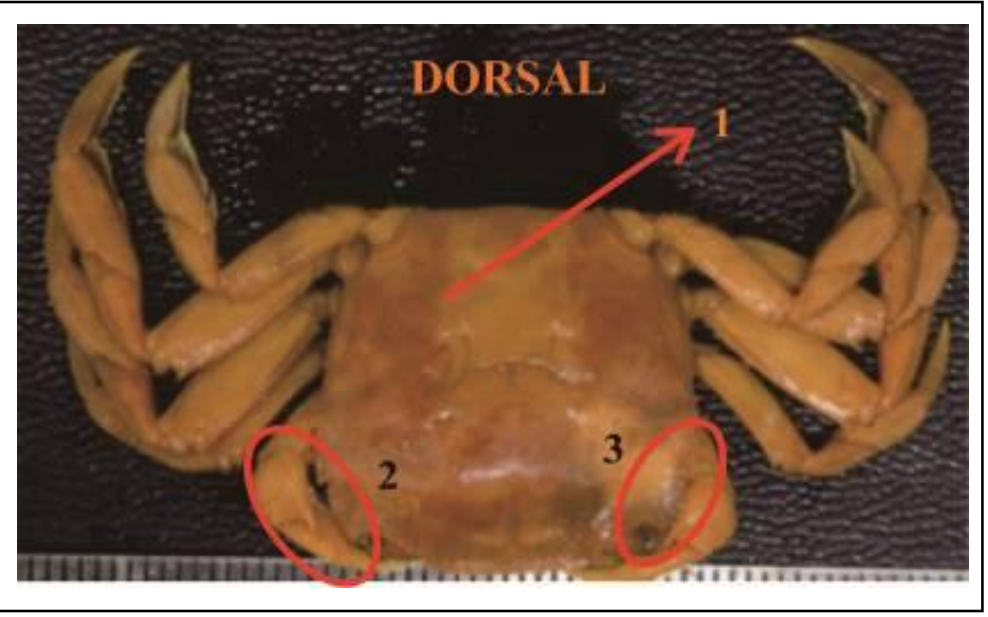

Gambar 8. Bagian tubuh kepiting Familia Grapsidae-subfamilia Varuninae: 1) Karapas; 2). Chela; 3) Bagian Anterolateral (Sumber Gambar: Dokumentasi Pribadi).

Jenis kepiting lain yang didapatkan adalah kepiting dari familia Ocypodidae. Kepiting ini memiliki habitat di zona intertidal dan tersembunyi, sehingga seringkali disebut sebagai kepiting hantu. Jenis kepiting dari familia Ocypodidae yang didapatkan adalah kepiting genus Uca dan genus Ocypode. Kepiting dari genus $U c a$ memiliki karakteristik yang mudah dikenali pada bagian karapasnya yaitu berbentuk heksagonal, trapesium atau oval. Selain genus ini memiliki sepasang chela yang salah satunya memiliki ukuran lebih besar dari yang lainnya. Bentuk lain yang menjadi ciri genus ini yaitu adanya bagian orbitofrontal yang melebar dan bagian anterolateral yang cenderung pendek dan tampak menyudut (Lihat gambar 9). Sementara itu, bagian posterolateral melengkung dan bergabung dengan bagian anterolateral yang menyudut. Chela umumnya memiliki warna yang terang ketika kepiting masih hidup. Ketika sudah mati hal yang dapat diidentifikasi dari kepiting ini adalah adanya bagian tuberkel atau gigi Chela. Antara satu tuberkel dengan tuberkel yang lain terdapat jarak yang cukup renggang dan kasar (Shih, et al, 2013). 


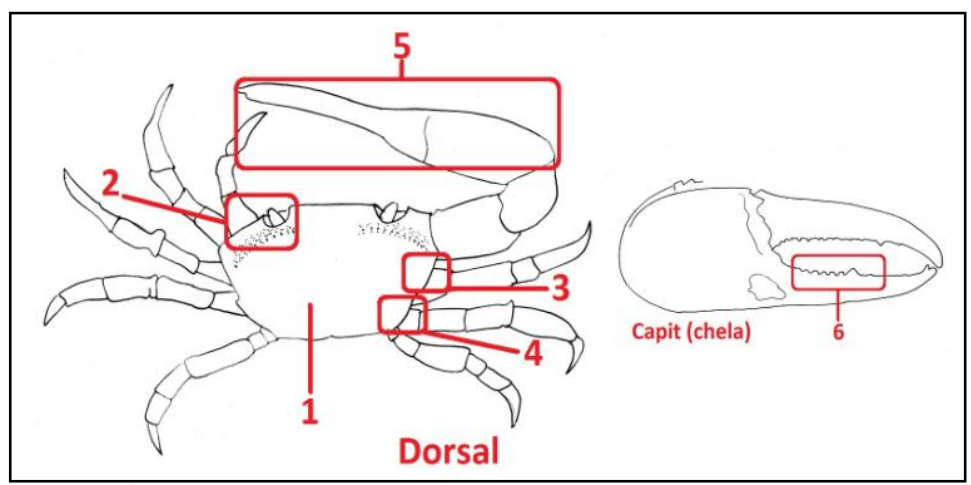

Gambar 9. Bagian tubuh kepiting Genus Uca: 1) Karapas;, 2). Bagian Orbitofrontal;, 3) Bagian Anterolateral; 4) Bagian Posterolateral; 5). Chela;, 6) Tuberkel (Sumber Gambar: modifikasi dari Shih, et al., 2013)

Sementara itu, kepiting dari Genus Ocypode karapas berwarna biru keabu-abuan tanpa gigi anterolateral. Ciri paling khas dari Ocypode ceratophthalma adalah matanya yang menjulang ke atas dan panjang di atas kornea.
Pada bagian chelae terdapat gerigi tumpul atau menajam. Pada bagian mandibular palp terdapat seta yang panjang (Gambar 3). Selain itu kepiting ini juga dapat diidentifikasi dari bentuk karapasnya yaitu kotak (Ng, 1998).

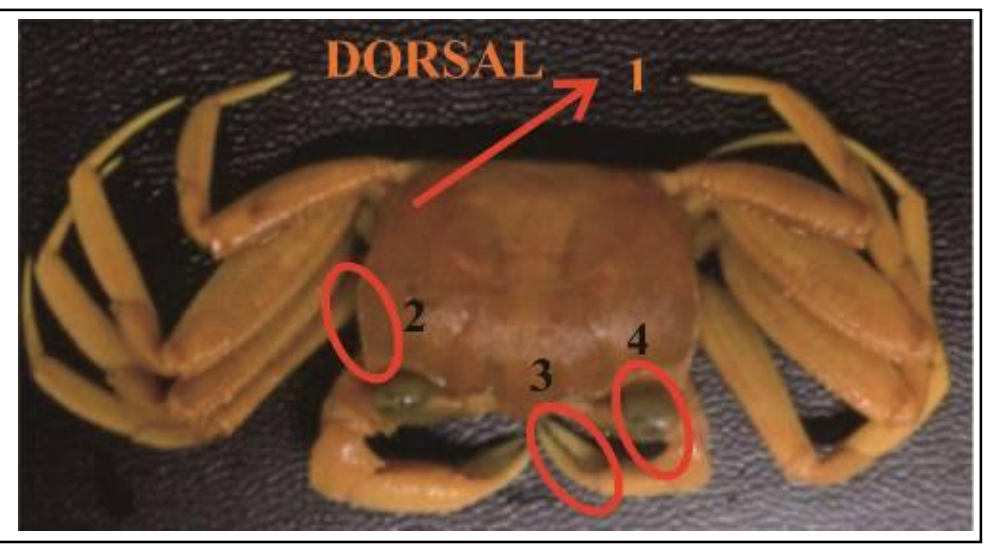

Gambar 3. Bagian tubuh kepiting Genus Oycpode: 1) Karapas; 2) Bagian Anterolateral; 3) Chela; 4) Eyestalk (Sumber Gambar: Dokumentasi Pribadi).

Kepiting berikutnya yang diidentifikasi adalah kepiting dari familia Raninidae. Kepiting ini sering disebut sebagai kepiting katak karena bentuk karapasnya yang menyerupai bentuk tubuh katak. Jenis yang didapatkan dari familia ini adalah genus Ranina. Genus ini karapas berbentuk oval dan memanjang secara longitudinal. Selain itu dapat dijumpai granula yang tersebar secara acak dan menutupi bagian dorsal karapas. Karakteristik lain dari kepiting ini yaitu adanya Chela dan Cheliped yang berbentuk memipih dan seakan-akan berbentuk seperti spatula (Gambar 4). Bagian Chela tampak membengkok ke arah dalam. Bagian dalam dari cheliped tersusun dari banyak gigi $(\mathrm{Ng}$, 1998). 


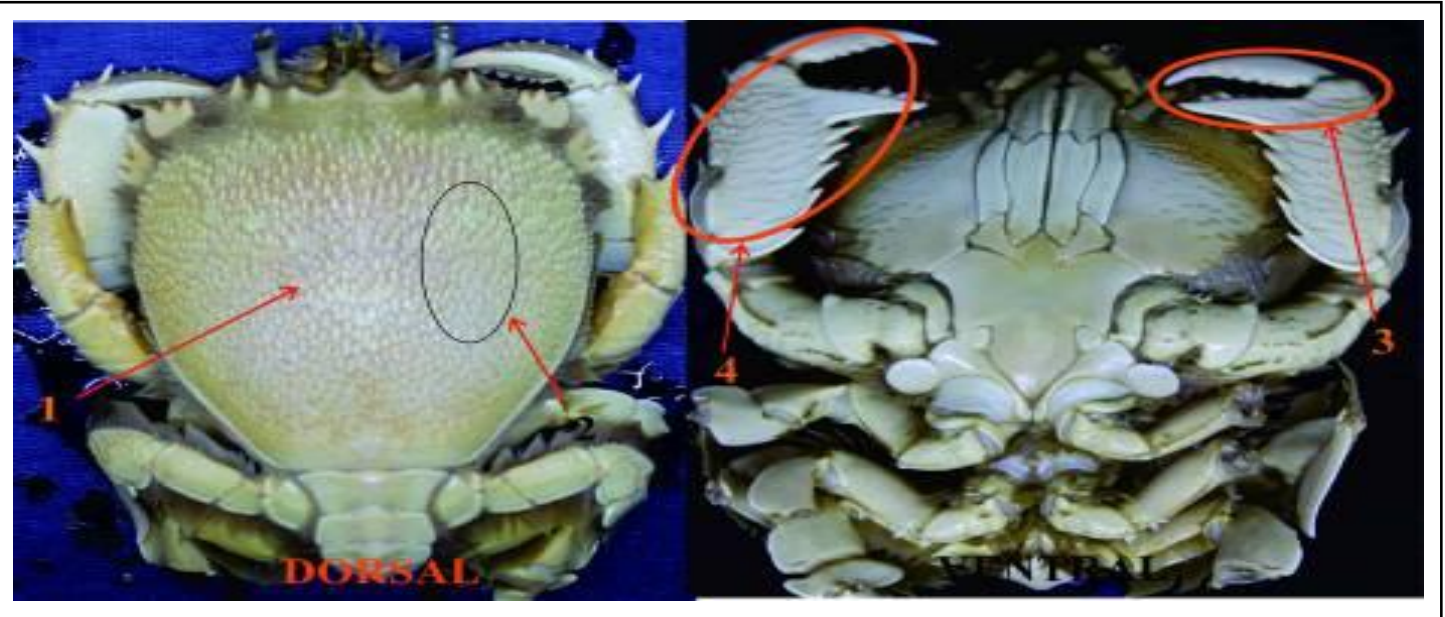

Gambar 4. Bagian tubuh kepiting Genus Ranina: 1). Karapas;, 2) Tekstur Granula; 3) Chela; 4) Cheliped (Dokumentasi Pribadi).

\section{Spesimen Kepiting Air Tawar}

Spesimen yang diidentifikasi termasuk ke dalam jenis kepiting air tawar diwakili oleh satu familia, yaitu familia Parathelpusidae. Habitat spesifik dari jenis kepiting ini yaitu di dataran rendah hingga daerah pegunungan, secara khusus di perairan terbuka serta habitat perairan darat. Familia ini memiliki sebelas genus, namun dalam penelitian ini yang didapatkan dan diidentifikasi hanya satu genus saja, yaitu genus Parathelphusa. Karakter diagnostik yang dimiliki oleh genus ini yaitu: spina pada subterminal bagian dorsal menajam pada beberapa bagian lengan kaki; crista postorbital bertemu pada tepi anterolateral antara gigi anterolateral pertama dan kedua atau dasar dari gigi kedua; keseluruhan gigi anterolateral pertama selalu penuh; postorbital crista betemu dengan tepi anterolateral pada posisi antara gigi anterolateral pertama dan kedua. Selain itu juga umumnya kepiting ini memiliki bentuk karapas yang oval dengan panjang dan lebar karapas yang sama (Gambar 5) (Ng, 2004).

\section{Karakter diagnostik tiap jenis kepiting infraordo Brachyura}

Berdasarkan hasil analisis, terdapat karakter diagnostik tiap kepiting yang telah diidentifikasi yang ditunjukkan pada Tabel 1 .

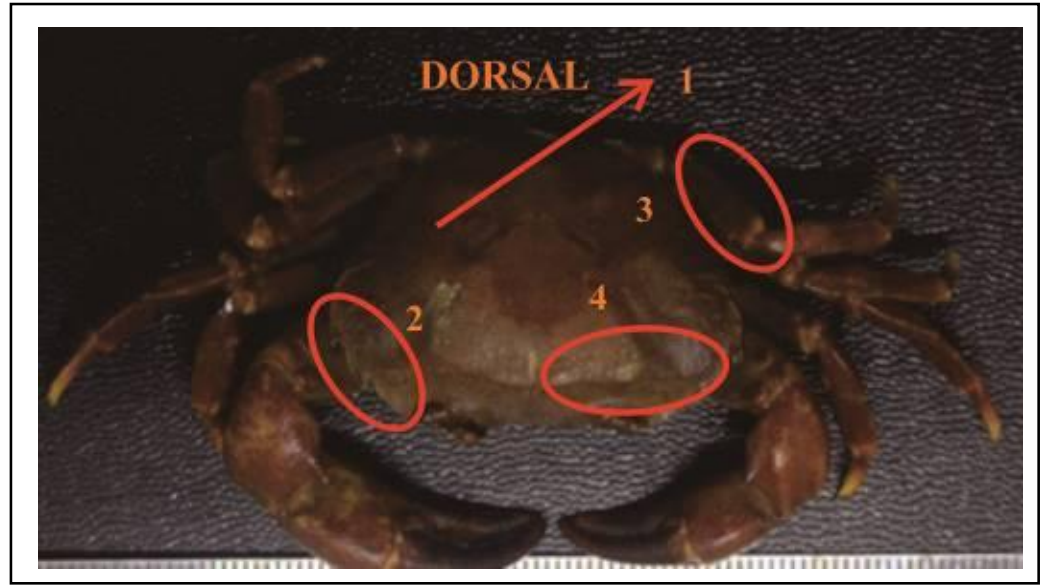

Gambar 5. Bagian tubuh kepiting Genus Parathelphusa: 1) Karapas; 2) Bagian Anterolateral; 3) Lengan kaki dengan spina; 4) Cristal Post-orbital (Dokumentasi Pribadi). 
Tabel 1. Karakter diagnostik karapas dan capit (chela)

\begin{tabular}{|c|c|c|c|}
\hline No & Kelompok & Karakter & Keterangan \\
\hline \multirow[t]{3}{*}{1} & Genus Galene & Karapas & Persegi panjang-melonjong \\
\hline & & Ornamentasi Karapas lateral & $\begin{array}{l}\text { Sulcus di fronto median, tiga spina } \\
\text { di anterolateral }\end{array}$ \\
\hline & & Ornamentasi Karapas dorsal & $\begin{array}{l}\text { Lobus mesogastris seperti botol, } \\
\text { Cardiac region ada tiga bagian } \\
\text { yang menonjol }\end{array}$ \\
\hline \multirow[t]{3}{*}{2} & Genus Pilumпиs & Karapas & Persegi dengan sudut tumpul \\
\hline & & Ornamentasi Karapas lateral & Empat spina di anterolateral \\
\hline & & Ornamentasi Karapas dorsal & $\begin{array}{l}\text { Lobus epigastris oval, Lobus } \\
\text { mesogastris suboval }\end{array}$ \\
\hline \multirow[t]{2}{*}{3} & Genus Portunus & Karapas & heksagonal \\
\hline & & Ornamentasi Karapas lateral & $\begin{array}{l}\text { Frontal terdapat empat lobus, } \\
\text { terdapat tujuh spina yang } \\
\text { menumpul dan menajam, } \\
\text { anterolateral terakhir ada spina } \\
\text { yang menajam }\end{array}$ \\
\hline \multirow[t]{2}{*}{4} & Familia Grapsidae- & Karapas & Persegi \\
\hline & subfamilia Sesarminae & Ornamentasi Karapas lateral & $\begin{array}{l}\text { Punggung lateral miring, bagian } \\
\text { anterolateral dan posterolateral } \\
\text { tidak terlihat batas jelas, memiliki } \\
\text { satu sampai dua gigi di bagian } \\
\text { anterior }\end{array}$ \\
\hline \multirow[t]{3}{*}{5} & Familia Grapsidae- & Karapas & Persegi \\
\hline & subfamilia Varuninae & Ornamentasi Karapas lateral & $\begin{array}{l}\text { Tepi depan lurus, memiliki tiga } \\
\text { gigi anterolateral }\end{array}$ \\
\hline & & Capit (chela) & Dactylus, carpus, propodus pipih \\
\hline \multirow[t]{3}{*}{6} & Genus $U c a$ & Karapas & Heksagonal, trapesium, oval \\
\hline & & Ornamentasi Karapas lateral & $\begin{array}{l}\text { Anterolateral pendek, } \\
\text { mencembung dan menyudut }\end{array}$ \\
\hline & & Capit (chela) & $\begin{array}{l}\text { Salah satu pasang capit membesar, } \\
\text { gigi capit dengan tuberkel kasar } \\
\text { dan berjarak. }\end{array}$ \\
\hline \multirow[t]{3}{*}{7} & Genus Ocypode & Karapas & Persegi \\
\hline & & Ornamentasi Karapas lateral & $\begin{array}{l}\text { Tidak memiliki gigi anterolateral, } \\
\text { batang mata memanjang }\end{array}$ \\
\hline & & Capit (chela) & gigi capit umumnya tumpul \\
\hline \multirow[t]{3}{*}{8} & Genus Ranina & Karapas & Oval longitudinal \\
\hline & & Ornamentasi Karapas Dosal & Granula tersebar merata \\
\hline & & Capit (chela) & $\begin{array}{l}\text { Chela dan Cheliped pipih, Chela } \\
\text { seperti spatula }\end{array}$ \\
\hline \multirow[t]{3}{*}{9} & Genus Parathelpusidae & Karapas & Oval \\
\hline & & Ornamentasi Karapas Dosal & $\begin{array}{l}\text { Post-Orbital Crista terletak antara } \\
\text { gigi anterolateral pertama dan } \\
\text { kedua }\end{array}$ \\
\hline & & Ornamentasi Karapas Lateral & $\begin{array}{l}\text { Subterminal bagian dorsal } \\
\text { menajam }\end{array}$ \\
\hline
\end{tabular}

\section{Simpulan}

Karakter karapas dan capit (chela) yaitu meliputi: 1) bentuk karapas; 2) ornamentasi karapas bagian lateral dan dorsal; 3) salah satu capit membesar; 4) tuberkula pada gigi capit; dan 5) bentuk capit dapat digunakan untuk mengidentifikasi jenis kepiting infraordo Brachyura. Karakter morfologi karapas dan capit (chela) ini dapat dijadikan referensi untuk identifikasi fragmen fosil kepiting yang dijumpai di Indonesia terutama di Pulau Jawa. 


\section{Daftar Pustaka}

Davie, P.J.F., (1987). A New Species and New Records of Portunus (Decapoda: Portunidae) from Northern Australia. Memoirs of the Queensland Museum. 25(1): 227-231.

Davie, P.J.F., (1993). A New Species of Sesarmine Crab (Brachyura: Grapsidae) form Japan and Taiwan, previously known as Sesarma erythodactyla Hess, 1865. Crustacean Research. 22: 65-74.

Lemaitre, R., Campos, N.H., Maestre, E.A.V., and Windsor, A.M. (2013). Discovery of an alien crab, Scylla serrata (Forsskal, 1755) (Crustacea: Decapoda: Portunidae), from the Caribbean coast of Colombia. BioInvasion Records. 2(4): 311-315.

Moraes, S.A.S.N., Alencar, C.E.R.D., Thomsen, E., and Freire, F.A.M., (2015). New Record of the hairy crab Pilumnus dasypodus (Decapoda, Brachyura, Pilumnidae) in Northeastern Brazil. The Journal of biodiversity data. 11(2): 1-5.

Morris, R.H., Abbott, D.P., and Haderlie, E.C., (1980). Intertidal Invertebrates of California. California, Stanford University Press, pp. 592-630.

Ng, P.K.L., (1998). Crabs. In: Carpenter, K.E. and Niem, V.H. (eds.) The Living Marine Resources of The Western Central Pacific Vol.2. Rome, Food and Agriculture Organization of United Nations, pp. 10451083.
Ng, P.K.L., (2004). Crustacea: Decapoda, Brachyura. In: Yule, C.M. and Yong, H.S. (eds.) Freshwater Invertebrates of the Malaysian Region. Kuala Lumpur, Academy of Sciences Malaysia, pp. 311336.

Ng, P.K.L., and Tan, L.W.H. (1984) The IndoPacific Pilumnidae I. Description of Four New Species of the Genus Pilumnus Leach, 1815, and Definition of a New Genus, Bathypilumnus. Journal of The Singapore National Academy

Schultz, G., (2014). Evolution of Crabs - history and deconstruction of a prime example of convergence. Zoology. 83(2): 87-105.

Schweitzer, C.E., Feldmann, R.M., and Bonadio, C., (2009). A new family of brachyura (Crustacea: Decapoda: Goneplacoidea) from the Eocene of Java, Indonesia. Scripta Geol. 138: 1-10.

Shih, His-Te, Komai, T., and Liu, Min-Yun., (2013). A new species of fiddler crab from the Ogasawara (Bonin) Islands, Japan, separated from the widely-distributed sister species Uca (Paraleptuca) crassipes (White, 1847) (Crustacea: Decapoda: Brachyura: Ocypodidae). Zootaxa. 3746 (1): 175-193.

Valinassab, T., Fatemi, S.M.R.F., and Ghotbeddin, N. (2012). First Record of Galene bispinosa Herbst, 1783 [Decapoda; Brachyura; Galenidae] from the Gulf of Oman, Iran. World Applied Science Journal 17(4): 439-441. 